\title{
Egg yolk antibodies (Ig Y) and its relevance in animal and human health-An updated review
}

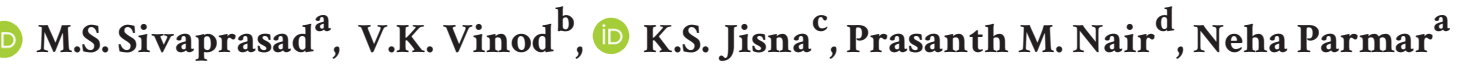

\author{
${ }^{a}$ MVSc Scholar, Division of Veterinary Public Health, ICAR-Indian Veterinary Research Institute, Izatnagar, \\ Bareilly-243 122, Uttar Pradesh, India \\ ${ }^{\mathrm{b}}$ Assistant Professor, Department of VPH, CVAS Pookode and PhD Scholar, Division of Veterinary Public Health, \\ ICAR-Indian Veterinary Research Institute, Izatnagar, Bareilly-243 122, Uttar Pradesh, India \\ ${ }^{c}$ MVSc Scholar, Division of Animal Reproduction, ICAR-Indian Veterinary Research Institute, Izatnagar, \\ Bareilly-243 122, Uttar Pradesh, India

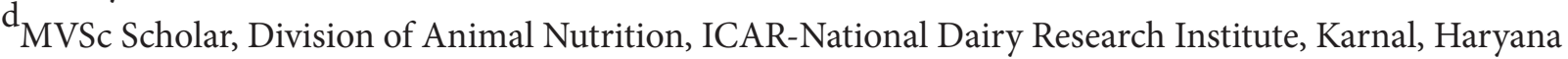

Corresponding author: M.S. Sivaprasad | email: sivaprasadms2011@gmail.com

Co-author: VKV: vinodvk@kvasu.ac.in; KSJ: jisnaks2012@gmail.com; PMN: prasanthmnair07@gmail.com NP: npvet36@gmail.com

Received: 09-10-2020, Accepted: 23-11-2020, Published online: 01-12-2020

\begin{abstract}
Egg yolk represents an alternate source of antibody and provides some advantages over mammalian serum immunoglobulins. The principal immunoglobulin in avian blood is Immunoglobulin Y (IgY) and is transferred to egg yolk and then to their offspring and thus makes it possible for the non-invasive harvesting of antibodies in higher amount from eggs. Moreover, due to the structural differences and phylogenetic variations, $\operatorname{IgY}$ is more acceptable than mammalian antibodies for diagnostic purposes, as it does not interfere with mammalian antibodies and shows greater avidity for proteins retained in mammals. As a therapeutic and diagnostic tool, IgY has wide application in animal and human health. The emergence of drug resistance organisms causing respiratory tract infections is a critical problem for the health care system worldwide. Passive immunization is a potential alternative for this. Recent studies on the diagnosis and therapeutic effects of IgY against SARS-CoV-2 indicates the importance of this technique in the present context. This review refers to the use of IgY antibodies from chicken egg yolks against the infection caused by bacteria, viruses (including SARS-CoV-2) and parasites in human beings and in animals in addition to its use in food preservation, anti tumour and anti allergic activities.
\end{abstract}

Keywords: Egg yolk antibodies (IgY); human health; SARS-CoV-2; Egg yolk

doi: https://doi.org/10.51128/jfas.2020.A015 | How to cite this article: Sivaprasad, M.S., Vinod, V.K., Jisna, K.S., Prasanth, M. N. and Neha, P 2020. Egg yolk antibodies (IgY) and its relevance in animal and human health-An updated review. Journal of Food and Animal Sciences, 01(02): 81-86. Copyright: Sivaprasad et al., 2020. Open Access. This article is distributed under the terms of the Creative Commons Attribution 4.0 International License (http://creativecommons.org/licenses/by/4.0/), which permits unrestricted use, distribution, and reproduction in any medium, provided you give appropriate credit to the original author(s) and the source, provide a link to the Creative Commons license, and indicate if changes were made. The Creative Commons Public Domain Dedication waiver (http://creativecommons.org/publicdomain/zero/1.0/) applies to the data made available in this article, unless otherwise stated. 


\section{Introduction}

IgY-technology (the production and extraction of specific IgY antibodies from egg yolk) is a novel method to produce antibodies for therapy and prophylaxis (Leiva et al., 2020). Protein molecules produced by the body in response to an antigen are called antibodies and are widely used in therapy, diagnosis and research due to their unique ability to bind with the precise targets. In the current scenario major chunk of available antibodies produced are of mammalian origin, especially from small rodents (Michael et al., 2010). One of the major disadvantages in using lab animals for the production of antibodies is the pain and suffering of animals during the procedures such as immunization, blood collection and sacrifice (Narat et al., 2003). Here comes the importance of noninvasive method like the usage of eggs, from which not only produce more amount of antibodies (IgY) with higher specificity compared to lab animals like rodents but also eliminates the ethical issues. (Narat et al., 2003, Schade et al., 1996).

In hens, $\operatorname{IgY}$ is transferred from blood and accumulates in egg (yolk) and then to their offspring. Hens are capable of producing 100 to $150 \mathrm{mg}$ of IgY antibodies per yolk, in which 1 to $10 \%$ are specific IgYs in nature (Michael et al., 2010). In an year, a normal hen produces an average of 300 eggs which yield approximately 18 to $25 \mathrm{~g}$ of IgY antibody (Pauly et al., 2011). While coming to the cost of maintenance, a hen is less expensive to maintain than lab animals like rabbits and mice. From the point of animal and human health, IgY antibodies are used in immunotherapy (Rahman et al., 2013), immunodiagnostics (Cai et al., 2012), as a functional food (Horie et al., 2004), in neutralization of bacterial toxins (LeClaire et al., 2002) and venom of animals (Mendoza et al.,2012). Fc portion of IgY immunoglobulin is not capable of activating the complement system in humans (Larsson et al., 1992) by binding with protein $G$ (Akerstrom et al., 1985) and to the rheumatoid factor (Larsson et al., 1991). $\mathrm{IgY}$ is more suitable for diagnosis as it displays greater avidity for mammalian conserved proteins and due to phylogenetic distance and structural differences when compared with mammalian antibodies (Gassmann et al., 1993).

\section{Production of IgY immunoglobulin}

Single antigens (Nucleic acids, polysaccharides, proteins) and complex type antigen such as bacterial, virus, and parasite are being used to produce specific IgY in birds (Chalghoumi et al., 2009). In hens of seven to eight weeks of age, 10-100 $\mu \mathrm{g}$ (per ml) of antigen is injected in two to three sites (Michael et al., 2010) by intramuscular (I/M) route, usually in the breast muscle and leg muscle is usually avoided as it causes lameness (Schade et al., 1996). Oral administration of antigen can also be performed (Thibodeau et al., 2017). Different antigen concentrations can be combined with adjuvants as the induction of high antibody titer depends on the use of adjuvants and Freund's Complete Adjuvant (FCA) is commonly is used due to its greater potential to induce antibodies in laboratory animals though it can cause severe inflammation at the site of injection (Chalghoumi et al., 2009). The titer of antibodies are influenced by a number of other factors also, like the type of antigen and dose, mode of application, frequency of inoculation, age and development stage of birds (Schade et al., 2005,Chalghoumi et al., 2009) and the higher titer can be maintained by booster inoculations for up to 150 days (Meenatchisundaram et al., 2011).

\section{Inoculation}

Minimum of two inoculations should be performed at an interval of four to six weeks before the period of egg laying. After 14 days of last immunization, IgY titer must be assessed. If the antibody titer is found to be decreasing more immunizations should be done during the egg laying period to increase titers (Schade et al., 1996). The number of injections required depends up on the dose and type of the antigen, and the adjuvant used. Highly purified IgY can be obtained by removal of lipid components from egg yolk, followed by precipitation of IgY with ammonium sulfate (NH4)2SO4 (20\%) (Araújo et al., 2010) supplemented by sodium chloride $(\mathrm{NaCl})$ and addition or by ultra-filtration technique prior to ion exchange chromatography or gel filtration. Ethanol precipitation method can also be used at lower temperatures for purification of Immunoglobulin (Akita et al., 1992).

\section{Applications of $\operatorname{IgY}$ in Therapeutics and prophylactics}

The main advantage of IgY polyclonal antibody against infectious diseases is that it minimizes the risk of microbial resistance since it requires multiple 


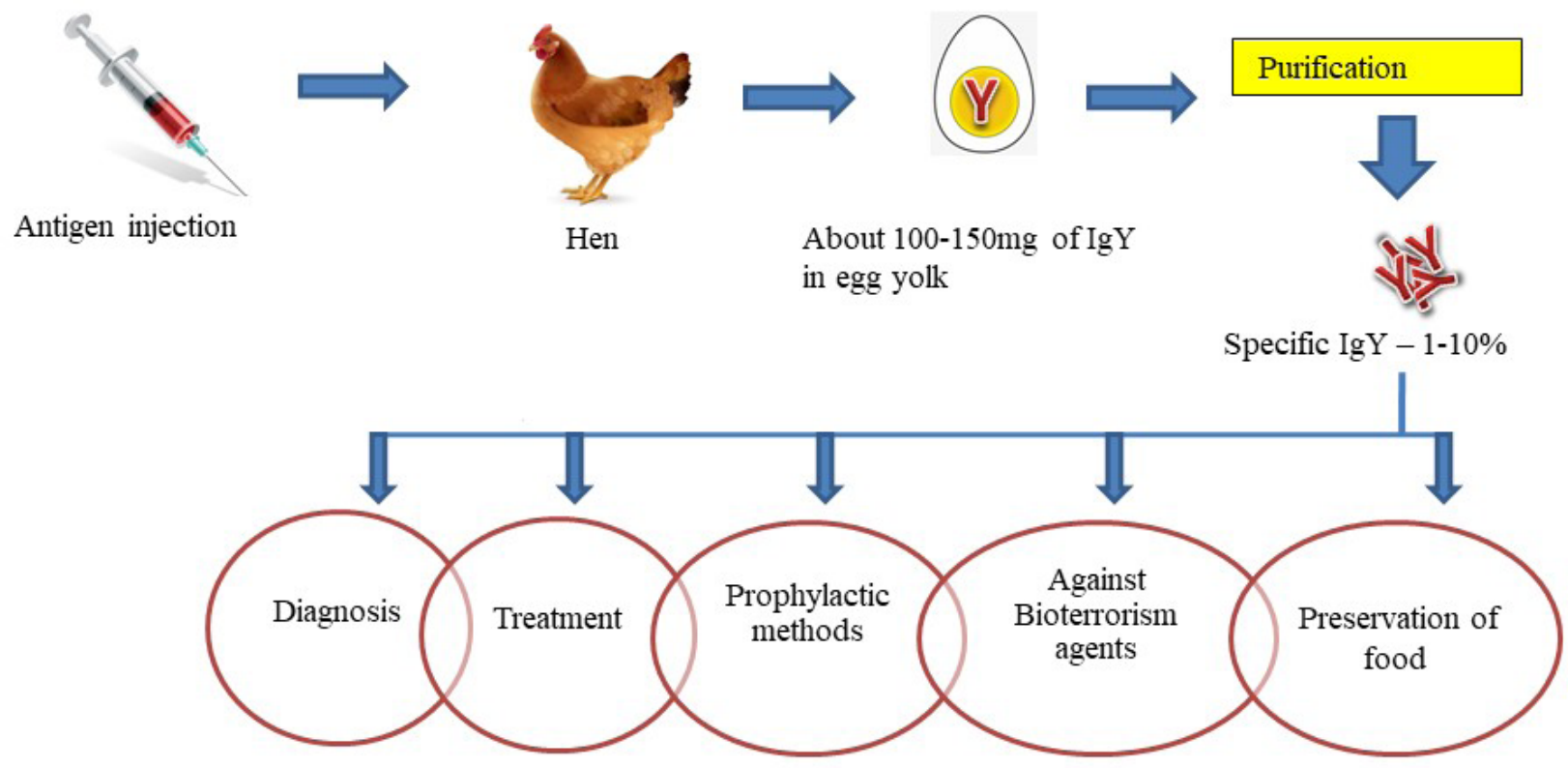

Figure 1: Production and application of IgY antibodies

genes for its synthesis (Rahman et al., 2013). IgY have shown antibacterial activity against Salmonella typhimurium ( $\mathrm{Li}$ et al., 2016), C. difficile infection, (Pizarro-Guajardo et al., 2017), H. pylori (Malekshahi et al., 2011) and it has therapeutic effect against acne caused by Propionibacterium acnes (Revathy et al., 2017). IgY shows greater efficacy against bovine group A Rotavirus (RVA) (Oral administration) and against dengue fever, (Fink et al., 2017). Nasal, oral or spray applications of IgY are used against avian influenza A virus (H5N1) strain are found effective (Wallach et al., 2011).

IgY obtained from geese eggs were found to be effective against Andes virus (ANDV) (the etiological agent of the Hantavirus Pulmonary Syndrome (HPS)). They have prophylactic activity against Candida albicans, in elder peoples an oral gel preparation of IgY caused a reduction in the number of colony-forming units (CFU) on the oral cavity showing promise for prophylactic use against $C$. albicans oral infection (Tekeuchi et al., 2014). Sampaio et al., in 2014 found out that anti-T. evansi IgY when used in tandem with anti-hematozoa drugs increased the survival rates in animals. The antibodies are also shown anti tumor activity by inducing apoptosis in human breast cancer cells (Amirijavidv et al., 2016). IgY shows anti-obesity activity by inhibiting the dietary fat hydrolysis and thus reducing its intestinal absorption (Hirose et al., 2013).
Anti-allergic effect of specific IgY against the cytokines IL- $\beta 1$ and TNF- $\alpha$ in guinea pigs after inducing allergic rhinitis showed encouraging results (Wei-xu et al., 2016). Advantage of $\operatorname{Ig} Y$ as an antivenom over IgG is that it is easily and sufficiently purified and the absence of other serum proteins that would minimize the side effects due to nonspecific proteins. (Araujo et al., 2010, Sjostrom et al., 1994).

\section{Applications of IgY in diagnosis}

Fc portion of IgG react with the protein A of Staphylococcus aureus whereas the Fc portion of IgY does not react with protein A due to structural differences which makes IgY a relevant resource for more specific detection of different $S$. aureus strains and the toxins (Richman et al., 1982) and it was confirmed by high titer of IgY in ELISA and western blot technique (Walczak et al., 2016). Among the parasitic infections, the ability of IgY to detect the protozoan Toxoplasma gondii was checked by the development of IgY against the surface protein SAG1, which responded to the target antigen in ELISA and Western blot. (Cakir-Koc et al., 2015) Several authors have been investigating the potential of $\operatorname{IgY}$ in the detection of tumor markers. IgY against the antigenic peptide CA 15-3, is a widely used marker for breast cancer, and is used as a secondary antibody in sandwich ELISA for detecting CA 15-3 (Grzywa et al., 2014). 
Against SARS- CoV-2

IgY immunoglobulin have excellent pathogenneutralization in the respiratory tract and lungs, and has shown its efficacy to treat and prevent respiratory infections (Abbas et al., 2018). Overall significance for the use of monoclonal chicken egg yolk antibodies (IgY) using phage display method describes their potential passive immunotherapeutic application for the treatment and prevention of SARS CoV-2 infection, an approach that is easy, quick and safe to effectively treat patients. When compared to polyclonal antibodies, chicken monoclonal IgY antibodies proved to be more specific in the identification of a single unique epitope. Chicken scFv IgY antibodies produced against SARS CoV-2 spike protein (S) using phage display technology are expected to be a potential candidate for the development of antibody-based vaccines as an immunotherapy agent model for efficient mass production of high-affinity monoclonal IgY antibodies for the treatment of SARS CoV-2 spike protein (S) with standardized preparation for long-term effective use (Abbas et al., 2018).

\section{As an agent for preservation of food}

IgY produced against the Listeria monocytogenes showed an important inhibitory effect on the bacterial growth in the liquid medium and in the fish samples processed between $0^{\circ} \mathrm{C}$ and $6^{\circ} \mathrm{C}$ in a dosedependent manner which showed that anti-L. IgY monocytogenesis is a possible antimicrobial agent and can be used in the food industry (Sui et al., 1946).

\section{Protection against bioterrorism agent}

IgY produced against the Staphylococcal enterotoxin is capable of saving people exposed to the substance $\mathrm{B}(\mathrm{SEB})$ which is a possible biological weapon. The findings with Rhesus monkeys showed the animals received anti-SEB IgY $30 \mathrm{~min}$ before or $4 \mathrm{~h}$ after lethal exposure to SEB aerosol survived (LeClair et al., 2002).

\section{Conclusion}

The benefits of IgY includes, lack of reaction to mammalian Fc receptors, low cost of development and ease of extraction. Compared to IgGs in mammals, they have higher specificity of the target and higher avidity of binding. To obtain IgY from egg yolk, several extraction methods are available and the choice of the appropriate method depends on the purpose, which may require different degrees of purification, as well as the extraction size, cost and available technology. Besides, in view of its proven capacity to neutralize microorganisms, it is a valuable therapeutic resource which can be used in the case of antibiotic resistance and against the development of viral diseases for which there is very less number of anti-viral agents.

\section{Authorship contribution statement}

M.S. Sivaprasad: Conceptualization, Writing Original draft, Writing - review \& editing

V.K. Vinod: Writing - review \& editing

K.S. Jisna: Figure designing, Writing - review \& editing

Prasanth M. Nair: Writing - review \& editing

Neha Parmar: Writing - review \& editing

\section{Acknowledgments}

All the authors acknowledge and thank their respective Institutes and Universities.

\section{Funding}

This compilation is a review article written by its authors and required no substantial funding to be stated.

\section{Declaration of Competing Interest}

All authors declare that there exist no commercial or financial relationships that could, in any way, lead to a potential conflict of interest.

\section{References}

Abbas, A. T., El-Kafrawy, S. A., Sohrab, S. S., and Azhar, E. I. A. 2019. IgY antibodies for the immunoprophylaxis and therapy of respiratory infections. Human vaccines $\mathcal{E}$ immunotherapeutics. 15(1): 264-275.

Akerström, B., Brodin, T. H., Reis, K. and Björck, L. 1985. Protein G: a powerful tool for binding and detection of monoclonal and polyclonal antibodies. The Journal of immunology. 135(4): 2589-2592.

Amirijavid, S., Entezari, M., Movafagh, A., Hashemi, M., Mosavi-Jarahi, A. and Dehghani, H. 2016. Apoptotic killing of breast cancer cells by IgYs produced against a small 21 aminoacid epitope of the human TRAIL-2 receptor. Asian Pacific Journal of Cancer Prevention. 17(S3): 293-297.

Araújo, A. S., Lobato, Z. I. P., Chávez-Olórtegui, C., and Velarde, D. T. 2010. Brazilian IgY- 
Bothropsantivenom: Studies on the development of a process in chicken egg yolk. Toxicon. 55(4): 739-744.

Cai, Y. C., Guo, J., Chen, S. H., Tian, L. G., Steinmann, P., Chen, M. X., and Chen, J. X. 2012. Chicken egg yolk antibodies (IgY) for detecting circulating antigens of Schistosomajaponicum. Parasitology international. 61(3): 385-390.

Cakir-Koc, R. 2016. Production of anti-SAG1 IgY antibody against Toxoplasma gondii parasites and evaluation of antibody activity by ELISA method. Parasitology research. 115(8): 2947-2952.

Chalghoumi, R., Beckers, Y., Portetelle, D. and Théwis, A. 2009. Hen egg yolk antibodies (IgY), production and use for passive immunization against bacterial enteric infections in chicken: a review. Biotechnologie, Agronomie, Société et Environnement. 13(3): 295-308.

Fink, A. L., Williams, K. L., Harris, E., Alvine, T. D., Henderson,T.,Schiltz,J.,... andBradley,D.S.2017. Dengue virus specific IgY provides protection following lethal dengue virus challenge and is neutralizing in the absence of inducing antibody dependent enhancement. PLoS neglected tropical diseases. 11(7): e0005721.

Gassmann, M., Thömmes, P., Weiser, T., and Hübscher, U. 1990. Efficient production of chicken egg yolk antibodies against a conserved mammalian protein. The FASEB Journal. 4(8): 2528-2532.

Grzywa, R., Łupicka-Słowik, A., Walczak, M., Idzi, M., Bobrek, K., Boivin, S., ... and Sieńczyk, M. 2014. Highly sensitive detection of cancer antigen 15-3 using novel avian IgY antibodies. ALTEXAlternatives to animal experimentation. 31(1): 4352.

Hirose, M., Ando, T., Shofiqur, R., Umeda, K., Kodama, Y., Van Nguyen, S., ... and Nagaoka, S. 2013. Anti-obesity activity of hen egg anti-lipase immunoglobulin yolk, a novel pancreatic lipase inhibitor. Nutrition \& metabolism. 10(1): 1-6.

Horie, K., Horie, N., Abdou, A. M., Yang, J. O., Yun, S. S., Chun, H. N., ... and Hatta, H. 2004. Suppressive effect of functional drinking yogurt containing specific egg yolk immunoglobulin on Helicobacter pylori in humans. Journal of dairy science. 87(12): 4073-4079.

Larsson, A., Karlsson-Parra, A., and Sjöquist, J. 1991. Use of chicken antibodies in enzyme immunoassays to avoid interference by rheumatoid factors. Clinical chemistry. 37(3): 411-414.
Larsson, A., Wejåker, P. E., Forsberg, P. O. and Lindahl, T. 1992. Chicken antibodies: a tool to avoid interference by complement activation in ELISA. Journal of immunological methods. 156(1): 79-83.

LeClaire, R. D., Hunt, R. E., and Bavari, S. 2002. Protection against bacterial superantigen staphylococcal enterotoxin B by passive vaccination. Infection and immunity. 70(5): 22782281.

Leiva, C. L., Gallardo, M. J., Casanova, N., Terzolo, H., and Chacana, P. 2020. IgY-technology (egg yolk antibodies) in human medicine: a review of patents and clinical trials. International Immunopharmacology. 81: 106269.

Li, X., Yao, Y., Wang, X., Zhen, Y., Thacker, P. A., Wang, L., ... and $\mathrm{Xu}, \mathrm{Y}$. 2016. Chicken egg yolk antibodies ( $\operatorname{IgY}$ ) modulate the intestinal mucosal immune response in a mouse model of Salmonella typhimurium infection. International immunopharmacology. 36: 305-314.

Malekshahi, Z. V., Gargari, S. L. M., Rasooli, I. and Ebrahimizadeh, W. 2011. Treatment of Helicobacter pylori infection in mice with oral administration of egg yolk-driven anti-UreC immunoglobulin. Microbial pathogenesis. 51(5): 366-372.

Meenatchisundaram, S., Shanmugam, V. and Anjali, V. M. 2011. Development of chicken egg yolk antibodies against Streptococcus mitispurification and neutralizing efficacy. Journal of basic and clinical pharmacy. 2(2): 109.

Mendoza, J. C., Vivas, D., Rodríguez, E., Inga, R., Sandoval, G., Lazo, F. and Yarlequé, A. 2012. Eficacia experimental de anticuerposIgYproducidosenhuevos, contra el veneno de la serpiente peruana Bothropsatrox. Revista Peruana de Medicina Experimental y SaludPública. 29: 69-75.

Michael, A., Meenatchisundaram, S., Parameswari, G., Subbraj, T., Selvakumaran, R. and Ramalingam, S. (2010). Chicken egg yolk antibodies (IgY) as an alternative to mammalian antibodies. Indian J. Sci. Technol. 3(4): 468-474.

MurrayThomson, W.2014.Epidemiologyoforalhealth conditions in older people. Gerodontology. 31: 9-16.

Narat, M. 2003. Production of antibodies in chickens. Food Technologyand Biotechnology.41(3): 259-267.

Pauly, D., Chacana, P. A., Calzado, E. G., Brembs, B., and Schade, R. 2011. IgY technology: 
extraction of chicken antibodies from egg yolk by polyethylene glycol (PEG) precipitation. JoVE (Journal of Visualized Experiments). 51: e3084.

Pizarro-Guajardo, M., Díaz-González, F., ÁlvarezLobos, M., and Paredes-Sabja, D. 2017. Characterization of chicken $\operatorname{IgY}$ specific to Clostridium difficile R20291 spores and the effect of oral administration in mouse models of initiation and recurrent disease. Frontiers in cellular and infection microbiology. 7:365.

Rahman, S., Van Nguyen, S., Icatlo Jr, F. C., Umeda, K. and Kodama, Y. 2013. Oral passive IgY-based immunotherapeutics: a novel solution for prevention and treatment of alimentary tract diseases. Human vaccines Eimmunotherapeutics. 9(5): 1039-1048.

Revathy, J., Karthika, S., Sentila, R. and Michael, A. 2014. In vitro evaluation of the efficacy of chicken egg yolk antibodies ( $\mathrm{g}$ Y) generated against $\mathrm{P}$ ropionibacterium acnes. International journal of cosmetic science. 36(1): 68-73.

Richman, D. D., Cleveland, P. H., Oxman, M. N., and Johnson, K. M. 1982. The binding of staphylococcal protein A by the sera of different animal species. The Journal of Immunology.128(5): 2300-2305.

Sampaio, L. C. L., Baldissera, M. D., Grando, T. H., Gressler, L. T., de Menezes Capeleto, D., de Sa, M. F., ... and Stainki, D. R. 2014. Production, purification and therapeutic potential of egg yolk antibodies for treating Trypanosomaevansi infection. Veterinary Parasitology. 204(3-4): 96103.

Schade, R., Calzado, E. G., Sarmiento, R., Chacana, P. A., Porankiewicz-Asplund, J., and Terzolo, H. R. 2005. Chicken egg yolk antibodies (IgYtechnology): a review of progress in production and use in research and human and veterinary medicine. Alternatives to laboratory animals. 33(2): 129-154.

Schade, R., Staak, C., Hendriksen, C., Erhard, M., Hugl, H., Koch, G., ... and Spielmann, H. 1996.
The Production of Avian (Egg Yolk) Antibodies: IgY: The Report and Recommendations of ECVAM Workshop 211, 2. Alternatives to laboratory animals. 24(6): 925-934.

Sjostrom, L., Al-Abdulla, I. H., Rawat, S., Smith, D. C., \& Landon, J. (1994). A comparison of ovine and equine antivenoms. Toxicon. 32(4): 427-433.

Sui, J., Cao, L., and Lin, H. 2011. Antibacterial activity of egg yolk antibody (IgY) against Listeria monocytogenes and preliminary evaluation of its potential for food preservation. Journal of the Science of Food and Agriculture.91(11): 1946-1950.

Thibodeau, A., Fravalo, P., Perron, A., LaurentLewandowski, S. and Letellier, A. 2017. Production and characterization of antiCampylobacter jejuni IgY derived from egg yolks. Acta Veterinaria Scandinavica. 59(1): 80.

Toldrá, F., Aristoy, M. C., Part, C., Cerveró, C., Rico, E., Motilva, M. J. and Flores, J. 1992. Muscle and adipose tissue aminopeptidase activities in raw and dry-cured ham. Journal of Food Science. 57(4): 816-818

Walczak, M., Grzywa, R., Łupicka-Słowik, A., Skoreński, M., Bobrek, K., Nowak, D., ... and Sieńczyk, M. 2015. Method for generation of peptide-specific igy antibodies directed to Staphylococcus aureus extracellular fibrinogen binding protein epitope. Peptide Science. 104(5): 552-559.

Wallach, M. G., Webby, R. J., Islam, F., WalkdenBrown, S., Emmoth, E., Feinstein, R. and Gronvik, K. O. 2011. Cross-protection of chicken immunoglobulin $\mathrm{Y}$ antibodies against $\mathrm{H} 5 \mathrm{~N} 1$ and H1N1 viruses passively administered in mice. Clinical and Vaccine Immunology. 18(7): 1083-1090.

Wei-Xu, H., Wen-Yun, Z., Xi-Ling, Z., Zhu, W., LiHua, W., Xiao-Mu, W., ... and Guo-Zhu, H. 2016. Anti-Interleukin-1 beta/tumor necrosis factor-alpha IgY antibodies reduce pathological allergic responses in guinea pigs with allergic rhinitis. Mediators of inflammation. 2016. 